\title{
ISOLASI BAKTERI Salmonella paratyphi DAN Shigell dysentriae PADA AIR SUMUR YANG TERDAPAT DI DESA PAYA BAKUNG KECAMATAN HAMPARAN PERAK TAHUN 2021
}

\author{
Eka Margareta Sinaga ${ }^{1}$, Maniur Siahaan ${ }^{2}$, Mahyudi ${ }^{3}$ \\ Fakultas Farmasi dan Ilmu Kesehatan, Universitas Sari Mutiara Indonesia \\ Email : eka_margaret@yahoo.com \\ Fakultas Farmasi dan Ilmu Kesehatan, Universitas Sari Mutiara Indonesia \\ Email : abby2510.acs@gmail.com \\ Fakultas Farmasi dan Ilmu Kesehatan, Universitas Sari Mutiara Indonesia \\ Email : mahyudi43@gmail.com
}

\begin{abstract}
ABSTRAK
Air merupakan bahan alam yang diperlukan untuk kehidupan manusia sebagai media pengangkutan zat-zat makanan, juga merupakan sumber energi serta berbagai keperluan lainnya. Pemeriksaan Salmonella paratyphi dan Shigella dysentriae pada air sumur dilakukan karna dapat menyebabkan demam thipoid dan diare, yang disebabkan karena masyarakat membuat sumur terlalu dekat dengan septic tank dan kandang hewan sehingga air sumur yang digunakan untuk keperluan rumah tangga bisa terkontaminasi oleh bakteri tersebut. Penelitian ini bertujuan untuk mengisolasi bakteri Salmonella typhi dan Shigella dysentriae dari 20 sampel air sumur yang diambil di Desa Paya Bakung Kecamatan Hamparan Perak. Sampel diisolasi dengan Media yang digunakan yaitu Thioglycholat broth, Salmonella Shigella Agar (SSA) dan Mac Conkey Agar (MCA). Hasil identifikasi terhadap 20 sampel air sumur yang diambil di Desa Paya Bakung Kecamatan Hamparan Perak yaitu: dari 20 sampel terdapat 5 sampel yang tercemar bakteri Salmonella typhi, Salmonella paratyphi dan Shigella dysentriae. Saran Bagi masyarakat diharapkan untuk menjaga ke higenisan pada saat menggunakan air sumur dan sebaiknya pembuatan sumur gali lebih jauh dari sumber pencemaran yang berjarak sekitar 15 meter.
\end{abstract}

Kata Kunci : Air sumur, Bakteri Salmonella paratyphi dan Shigella dysentriae.

\section{ABSTRACT}

Water is a natural material needed for human life as a medium for transporting food substances, it is also a source of energy and various other purposes. Examination of Salmonella paratyphi and Shigella dysentriae in well water is carried out because they can cause typhoid fever and diarrhea, which is caused by people making wells close to septic tanks and animal cages so that well water used for household purposes can be contaminated by these bacteria. This study aims to isolate Salmonella typhi and Shigella dysentriae bacteria from 20 well water samples taken at Desa Paya Bakung Kecamatan Hamparan Perak. The samples were isolated with the media used, namely Thioglycholat broth, Salmonella Shigella Agar (SSA) and Mac Conkey Agar (MCA). The results of the identification of 20 well water samples taken at Desa Paya Bakung Kecamatan Hamparan Perak, namely: from 20 samples there were 5 samples that were contaminated with Salmonella typhi, Salmonella paratyphi and Shigella dysentriae bacteria. Suggestions For the community, it is expected to maintain hygiene when using well water and it is better to dig wells further from the source of pollution which is about 15 meters away.

Keywords : Well water, Salmonella paratyphi and Shigella dysentriae bacteria. 
Eka Margareta Sinaga et. all | Isolasi Bakteri Salmonella Paratyphi Dan Shigella Dysentriae Pada Air Sumur Yang Terdapat Di Desa Paya Bakung Kecamatan Hamparan Perak Tahun 2021

\section{PENDAHULUAN}

Air merupakan bahan alam yang diperlukan untuk kehidupan manusia, hewan dan tanaman yaitu sebagai media pengangkutan zat-zat makanan, juga merupakan sumber energi serta berbagai keperluan lainnya. Kebutuhan akan air bersih dari tahun ke tahun diperkirakan terus meningkat. Dalam peraturan pemerintah RI No. 82 Tahun 2001, mutu air ditetapkan melalui pengujian parameter fisika, parameter kimia, dan parameter mikrobiologi. ${ }^{1}$

Salmonella yang termasuk dalam family Enterobacteriaceae merupakan bakteri pathogen bagi manusia dan hewan. Angka kesakitan akibat infeksi bakteri salmonella sangat tinggi. Angka kejadian infeksi salmonella diseluruh dunia mencapai lebih dari 12,5 juta per tahun dan diamerika serikat diperkirakan sekitar 2 juta penderita salmonellosis setiap tahunnya. $^{2}$

$\begin{array}{rrr} & \text { Shigella merupakan bakteri } \\ \text { yang mampu bertahan hidup }\end{array}$

dilingkungan yang terkontaminasi serta keasaman saluran pencernaan manusia. Shigella penting karena bisa menimbulkan ancaman kesehatan masyarakat, khususnya di negara-negara terbelakang. Jika tidak diobati di host, infeksi dapat mematikan. Shigella dysenteriae ditemukan pada tahun 1896 oleh ahli mikrobiologi Jepang Kiyoshi Shiga. $^{3}$

Pemeriksaan Salmonella typhi dan Shigella dysentriae pada air sumur dilakukan karna demam thipoid di Indonesia masih relatif tinggi, serta masih banyak masyarakat di sini yang membuat sumur dekat dengan septic tank dan kandang hewan sehingga air sumur yang digunakan untuk keperluan rumah tangga bisa terkontaminasi oleh bakteri tersebut. Demam dan diare juga terkadang diderita oleh beberapa masyarakat Paya Bakung Kecamatan Hamparan Perak yang mungkin disebabkan oleh penggunaan air yang sudah terkontamisasi tersebut. ${ }^{4}$

\section{METODE PENELITIAN}

$$
\text { Jenis Penelitian ini }
$$
menggunakan metode Deskriptif kualitatif yaitu metode penelitian yang dilakukan dengan tujuan untuk mengetahui apakah air sumur yang berada di Desa Paya Bakung Kecamatan Hamparan Perak mengandung bakteri Salmonella paratyphi dan Shigella dysentriae.

\section{LOKASI PENELITIAN}

Lokasi pengambilan sampel dilakukan di Desa Paya Bakung Kecamatan Hamparan dan dibawa ke Laboratorium Kesehatan Daerah Medan untuk dilakukan pemeriksaan. 
Eka Margareta Sinaga et. all | Isolasi Bakteri Salmonella Paratyphi Dan Shigella Dysentriae Pada Air Sumur Yang Terdapat Di Desa Paya Bakung Kecamatan Hamparan Perak Tahun 2021

WAKTU PENELITIAN

Waktu penelitian dilaksanakan pada bulan April-Juni 2021.

\section{HASIL DAN PEMBAHASAN}

Berdasarkan hasil penelitian pemeriksaan bakteri Salmonella paratyphi dan Shigella dysentrise pada air sumur di Desa Paya Bakung Kecamatan Hamparan Perak, maka didapatkan hasil seperti Gambar dan tabel dibawah ini.

\section{Gambar 4.1 Hasil Pembiakan Pada Media Thioglycholat broth}
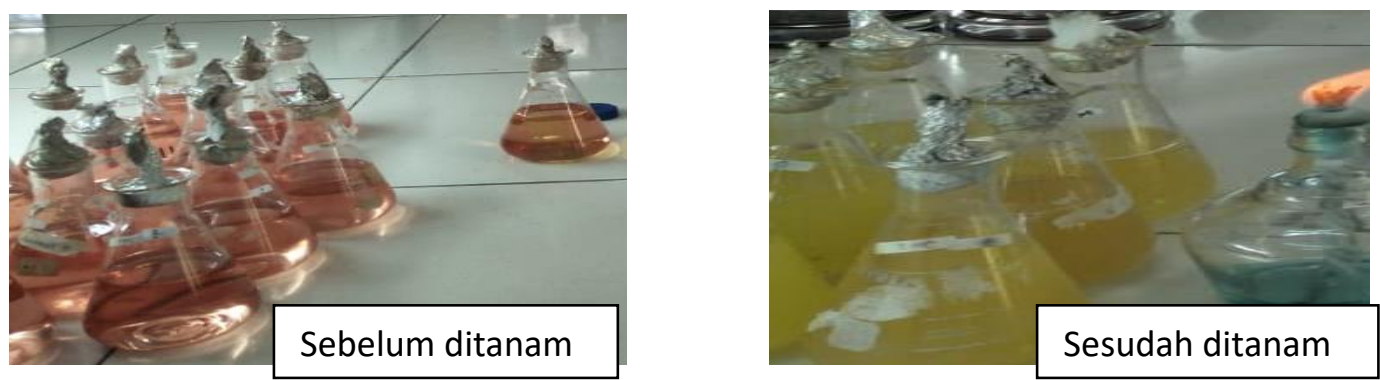

Dari gambar 4.1 diatas dapat disimpulkan bahwa, setelah diinkubasih dalam inkubator pada suhu 37C selama 24 jam, semua media Thioglycholat broth menjadi keruh menunjukan adanya pertumbuhan bakteri dengan kode sampel S1, S2, S3, S4, S5, S6, S7, S8, S9, S10, S11, S12, S13, S14, S15, S16, S17, S18, S19, dan S20. Selanjutnya dari media Thioglycholat broth ditanam kembali ke media MCA (Mac Conkey Agar) dan Media SSA (Salmonella Shigella Agar).

Gambar 4.2 Hasil Penanaman Pada Media MCA (Mac Conkey Agar) dan Media SSA (Salmonella Shigella Agar)

\begin{tabular}{|l|l|}
\hline Media MCA Sampel 3 & $\begin{array}{l}\text { Bentuk : Bulat } \\
\text { Pigmen : Jernih } \\
\text { Permukaan : Cembung } \\
\text { Tepi } \quad: \text { Rata } \\
\text { Sifat } \\
\text { Laktosa : Tidak Memfermentasikan }\end{array}$ \\
\hline
\end{tabular}


Eka Margareta Sinaga et. all | Isolasi Bakteri Salmonella Paratyphi Dan Shigella Dysentriae Pada Air Sumur Yang Terdapat Di Desa Paya Bakung Kecamatan Hamparan Perak Tahun 2021

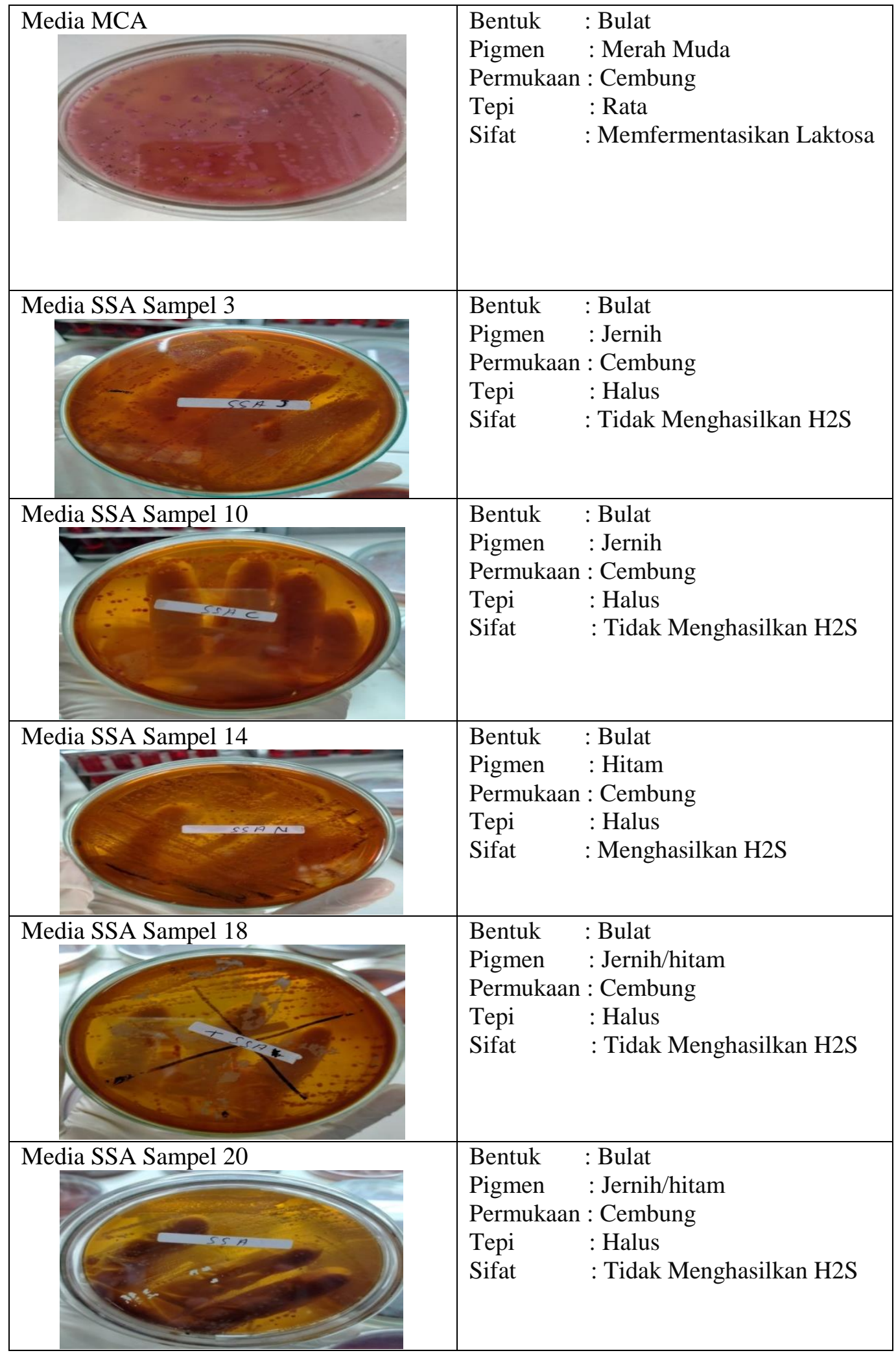

Dari gambar 4.2 diatas dapat disimpulkan bahwa, hasil pembiakan pada media MCA (Mac Conkey Agar) menunjukan bahwa semua sampel mengandung bakteri yaitu

\section{Universitas Sari Mutiara Indonesia}

DOI 
Eka Margareta Sinaga et. all | Isolasi Bakteri Salmonella Paratyphi Dan Shigella Dysentriae Pada Air Sumur Yang Terdapat Di Desa Paya Bakung Kecamatan Hamparan Perak Tahun 2021

pada sampel dengan kode S1, S2, S4, S5, S6, S7, S8, S9, S11, S12, S13, S15, S16, S17, dan S19 bentuk koloni bulat, permukaan cembung, tepian rata, warna koloni merah muda karena bakteri yang tumbuh memfermentasi laktosa dan 5 sampel yang tumbuh dengan kode sampel S3, S10, S14, S18, dan S20 media berubah warna menjadi kuning karena tidak memfermentasikan laktosa, sedangkan pada media SSA (Salmonella Shigella Agar) dari 20 sampel 5 yang tumbuh dengan kode sampel S3, S10, S14, S18, dan S20 dengan bentuk koloni bulat kecil, permukaan cembung, tepi halus, S3 dan S10 warna koloni jernih karena tidak menghasilkan H2S sedangkan S14, S18, dan S20 warna koloni hitam karena menghasilkan H2S.

\section{Gambar 4.1 Hasil Pembiakan Pada Media Thioglycholat broth}
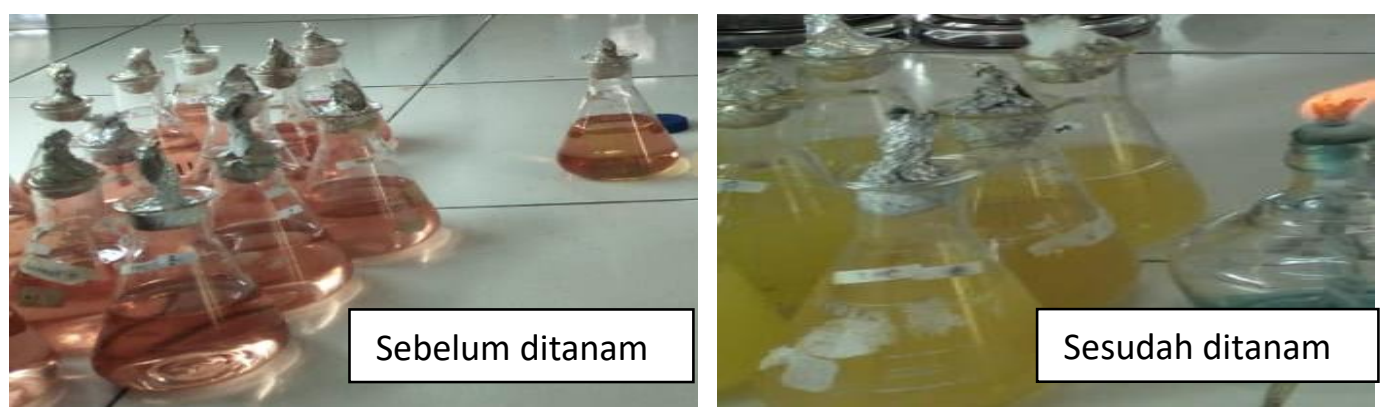

Dari gambar 4.1 diatas dapat disimpulkan bahwa, setelah diinkubasih dalam inkubator pada suhu 37C selama 24 jam, semua media Thioglycholat broth menjadi keruh menunjukan adanya pertumbuhan bakteri dengan kode sampel S1, S2, S3, S4, S5, S6, S7, S8, S9, S10, S11, S12, S13, S14, S15, S16, S17, S18, S19, dan S20. Selanjutnya dari media Thioglycholat broth ditanam kembali ke media MCA (Mac Conkey Agar) dan Media SSA (Salmonella Shigella Agar).

Gambar 4.2 Hasil Penanaman Pada Media MCA (Mac Conkey Agar) dan Media SSA (Salmonella Shigella Agar)

\begin{tabular}{|l|l|}
\hline Media MCA Sampel 3 & \begin{tabular}{l} 
Bentuk : Bulat \\
Pigmen : Jernih \\
Permukaan : Cembung \\
Tepi $\quad$ : Rata \\
Sifat $\quad$ : Tidak Memfermentasikan \\
\hline
\end{tabular} \\
\hline
\end{tabular}

\section{Universitas Sari Mutiara Indonesia}


Eka Margareta Sinaga et. all | Isolasi Bakteri Salmonella Paratyphi Dan Shigella Dysentriae Pada Air Sumur Yang Terdapat Di Desa Paya Bakung Kecamatan Hamparan Perak Tahun 2021

\begin{tabular}{|c|c|}
\hline Media MCA & $\begin{array}{ll}\text { Bentuk } & \text { : Bulat } \\
\text { Pigmen } & \text { : Merah Muda } \\
\text { Permukaan } & \text { : Cembung } \\
\text { Tepi } & \text { : Rata } \\
\text { Sifat } & \text { : Memfermentasikan Laktosa }\end{array}$ \\
\hline Media SSA Sampel 3 & $\begin{array}{ll}\text { Bentuk } & \text { : Bulat } \\
\text { Pigmen } & \text { : Jernih } \\
\text { Permukaan } & \text { : Cembung } \\
\text { Tepi } & \text { : Halus } \\
\text { Sifat } & \text { : Tidak Menghasilkan H2S }\end{array}$ \\
\hline Media SSA Sampel 10 & $\begin{array}{ll}\text { Bentuk } & \text { : Bulat } \\
\text { Pigmen } & \text { : Jernih } \\
\text { Permukaan } & \text { : Cembung } \\
\text { Tepi } & \text { : Halus } \\
\text { Sifat } & \text { : Tidak Menghasilkan H2S }\end{array}$ \\
\hline Media SSA Sampel 14 & $\begin{array}{ll}\text { Bentuk } & \text { : Bulat } \\
\text { Pigmen } & \text { : Hitam } \\
\text { Permukaan } & \text { : Cembung } \\
\text { Tepi } & \text { : Halus } \\
\text { Sifat } & \text { : Menghasilkan H2S }\end{array}$ \\
\hline Media SSA Sampel 18 & $\begin{array}{ll}\text { Bentuk } & \text { : Bulat } \\
\text { Pigmen } & \text { : Jernih/hitam } \\
\text { Permukaan } & \text { : Cembung } \\
\text { Tepi } & \text { : Halus } \\
\text { Sifat } & : \text { Tidak Menghasilkan H2S }\end{array}$ \\
\hline Media SSA Sampel 20 & $\begin{array}{ll}\text { Bentuk } & \text { : Bulat } \\
\text { Pigmen } & \text { : Jernih/hitam } \\
\text { Permukaan } & \text { : Cembung } \\
\text { Tepi } & \text { : Halus } \\
\text { Sifat } & : \text { Tidak Menghasilkan H2S }\end{array}$ \\
\hline
\end{tabular}

Dari gambar 4.2 diatas dapat disimpulkan bahwa, hasil pembiakan pada media MCA (Mac Conkey Agar) menunjukan bahwa semua sampel mengandung bakteri yaitu pada sampel dengan kode S1, S2, S4, S5, S6, S7, S8, S9, S11, S12, S13, S15, S16, S17, dan S19 bentuk koloni bulat, permukaan cembung, tepian rata, warna koloni merah

\section{Universitas Sari Mutiara Indonesia}

DOI 
Eka Margareta Sinaga et. all | Isolasi Bakteri Salmonella Paratyphi Dan Shigella Dysentriae Pada Air Sumur Yang Terdapat Di Desa Paya Bakung Kecamatan Hamparan Perak Tahun 2021

muda karena bakteri yang tumbuh memfermentasi laktosa dan 5 sampel yang tumbuh dengan kode sampel S3, S10, S14, S18, dan S20 media berubah warna menjadi kuning karena tidak memfermentasikan laktosa, sedangkan pada media SSA (Salmonella Shigella Agar) dari 20 sampel 5 yang tumbuh dengan kode sampel S3, S10, S14, S18, dan S20 dengan bentuk koloni bulat kecil, permukaan cembung, tepi halus, S3 dan S10 warna koloni jernih karena tidak menghasilkan H2S sedangkan S14, S18, dan S20 warna koloni hitam karena menghasilkan H2S.

Apabila masyarakat masih menggunakan air yang tercemar oleh bakteri Salmonella paratyphi, Salmonella paratyphi dan Shigella dysentriae untuk digunakan dalam kehidupan sehari-hari seperti mencuci alat-alat rumah tangga, menggosok gigi dan mengkonsumsinya dapat menimbulkan penyakit, dimana Salmonella paratyphi akan menyebabkan penyakit demam tifoid, Salmonella paratyphi akan menyebabkan penyakit demam paratifoid dan Shigella dysentriae akan menyebabkan penyakit disentri basiler.

Beberapa warga yang masih tinggal dilingkungan ini tidak bisa terhindar dari limbah perternakan, dan tidak dapat dipungkiri bahwa jarak sumber air sumur berada sangat dekat dengan sumber cemaran. Namun ada beberapa warga yang tidak menggunakan air sebagai bahan masak atau minum, kebanyakan dari mereka hanya menggunakan air sumur sebagai kebutuhan rumah tangga lainnya. Hal itu disebabkan karena kesadaran para warga bahwa air sumur dapat tercemar atau terkontaminasi dengan mudah. Tidak adanya pasilitas seperti air pam membuat warga kekurangan akan air besih.

Diperkirakan kedalaman sumur yang berada di Desa Paya Bakung Kecamatan Hamparan Perak ada yang tidak mencapai 11 meter dan terdapat sumber pencemaran air berjarak 3 meter, sedangkan jarak pencemaran minimal 15 meter dari sumur dan tidak semua masyarakat menggunakan air untuk minum. Oleh karena itu sumur hendaknya terletak di tempat yang aliran air tanahnya tidak tercemar dan setidaknya berjarak minimal 15 dari sumber pencemaran.

\section{KESIMPULAN}

Dari hasil penelitian terhadap 20 sampel dapat diambil kesimpulan bahwa air sumur yang berada di Desa Paya Bakung Kecamatan Hamparan ternyata 5 sumur yang tercemar bakteri pathogen Salmonella paratyphi dan Shigella dysentriae.

\section{Universitas Sari Mutiara Indonesia}


Eka Margareta Sinaga et. all | Isolasi Bakteri Salmonella Paratyphi Dan Shigella Dysentriae Pada Air Sumur Yang Terdapat Di Desa Paya Bakung Kecamatan Hamparan Perak Tahun 2021

\section{DAFTAR PUSTAKA}

Anonimus. (2010). Media Uji Pemecahan Komponen Makanan Oleh Mikroorganisme. Juni 2015; http://lordbroken.wodpress.co $\underline{\mathrm{m} / 2010 / 07 / 27 . h t m l}$.

Brooks, Misnadiarly dan Husjain. 2014. Mikrobiologi untuk Klinik dan Laboratorium. Jakarta: PT. Rineka Cipta.

Brooks, Radji Maksum, 2009,Buku Ajar Mikrobiologi Panduan Mahasiswa Farmasi Dan Kedokteran. Penerbit Buku KedokteranEGC, Jakarta.
Brooks, Sinta, dkk. 2016. Praktikum Mikrobiologi Dasar. Penerbit Buku CV Trans Info Media, Jakarta.

Brooks, Maria Dannessa Delost, $2018 . \quad$ Mikrobiologi Diagnostik Untuk Teknologi Laboratorium Medik. Penerbit buku Kedokteran (ECG).

Budiyanto, M. A. K. 2002. Mikrobiologi Terapan. Malang; UMM Prees.

Chandra, Budiman, 2005. Pengantar Kesehatan Lingkungan. Jakarta; Buku Kedokteran EGC. 